$\mathrm{Nr} 6$

KRAKÓW 2003

WARSZAWA-

ELIZA WAJDA, KATARZYNA ZALEWSKA

Akademia Pedagogiczna, Kraków

\title{
Struktura przestrzenno-organizacyjna korporacji General Motors
}

We współczesnym świecie rozwój gospodarczy jest procesem mającym w coraz większym stopniu wymiar międzynarodowy. Postęp techniczny sprawia, iż działalność gospodarcza rozszerza się poza granice jednego państwa i zaczyna obejmować swoim zasięgiem coraz większą część świata (Budnikowski 2001). Jednym z najważniejszych zjawisk XX w. stało się umiędzynarodowienie działalności gospodarczej. Bardziej zaawansowany i złożony etap procesu umiędzynarodowienia stanowi nasilający się proces globalizacji. Głównymi podmiotami tego procesu są korporacje transnarodowe stanowiące najsilniejszą i wiodąca grupę w gospodarce światowej.

Celem niniejszej pracy jest próba analizy struktury przestrzenno organizacyjnej firmy General Motors, zajmującej wysoką pozycję wśród wszystkich korporacji światowych.

Korporacja General Motors powstała w 1908 r. w Detroit w Stanach Zjednoczonych, pod kierownictwem Billy’ego Duranta, w wyniku połączenia z firmą Buick Motor Company. Jako druga dołączyła firma Olds Motor Work. Rok później General Motors wykupiła połowę udziałów firmy Okland Motor Corporation, a następnie w swoje struktury przyłączyła Cadillaca oraz Rapid Motor Company of Pontiac. Kolejnym krokiem w rozwoju firmy było stworzenie centrum badawczo-rozwojowego oraz specjalnego działu technicznego służącego firmie. Ważnym wydarzeniem było wynalezienie przez Karola Katteringa rozrusznika, który po raz pierwszy został zainstalowany w Cadillacu. Firma rozwijała się bardzo dynamicznie. Pokonując konkurencję wkroczyła na rynek europejski, gdzie nawiązała współpracę na terenie Niemiec z firmą Opel. Kolejnym etapem rozwoju General Motors była lokalizacja oddziałów produkcyjnych na terenie Europy. W dalszym etapie rozwoju korporacja zakłada nowe filie m.in. w Japonii, Chinach i różnych krajach Ameryki Południowej. W kolejnych latach powiększa się asortyment korporacji. Podczas II wojny światowej firma zmienia asortyment i produkuje sprzęt wojskowy i uzbrojenie. W $1971 \mathrm{r}$. pewną innowacją był wyprodukowany przez General Motors system nawigacji do statku Apollo 11 oraz wyprodukowanie pojazdu poruszającego się po księżycu - Lunar Roving Vehicle. Kolejnym krokiem w rozwoju firmy było podpisanie porozumienia z Isuzo Motors Cornitte i tym samym wzbogacenie asortymentu o produkcję ciężarówek. Firma rozszerzyła swoją działalność zdobywając rynek irański i koreański. Lata 80. przynoszą podpisanie porozumień z Susuki Motors Company, Toyota Motor Company, a także z Volvo. Firma dąży do wyposażania swoich samochodów w nowoczesną, inteligentną elektronikę, 
dzięki czemu podróżowanie samochodem będzie bezpieczniejsze, oszczędniejsze, a także ekologiczne.

ryc. 1 


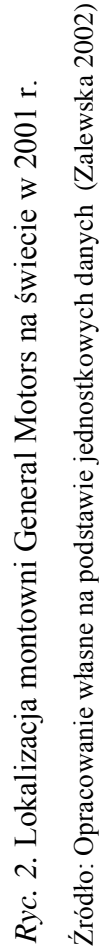


Główną siedzibą firmy General Motors jest Detroit w Stanach Zjednoczonych. Korporacja dzieli się na cztery główne grupy regionalne i posiada swe przedstawicielstwa $\mathrm{w}$ prawie 50 państwach (ryc. 1). Na świecie znajduje się 15 przedstawicielstw koncernu General Motors. Najwięcej skupionych jest na obszarze Europy (8), a także w Azji (4). Należy tu podkreślić, iż dane nie obejmują oddziałów znajdujących się na terenie Stanów Zjednoczonych. Przedstawicielstwa firmy zlokalizowane są głównie w stolicach państw. Warto także zwrócić uwagę, iż są to przeważnie państwa wysoko rozwinięte lub posiadające duży potencjał ekonomiczny.

W Europie zlokalizowano także największą liczbę montowni - 15, w Azji oraz w Ameryce Południowej po 7 (tab. 1). Ogółem w świecie znajduje się 41 montowni (ryc. 2). Te oddziały charakteryzuje większe rozproszenie.

Tabela 1. Lokalizacja przedstawicielstw i montowni według kontynentów w $2001 \mathrm{r}$.

\begin{tabular}{|l|c|c|}
\hline \multicolumn{1}{|c|}{ Kontynent } & $\begin{array}{c}\text { Liczba } \\
\text { przedstawi- } \\
\text { cielstw }\end{array}$ & $\begin{array}{c}\text { Liczba } \\
\text { montowni }\end{array}$ \\
\hline Europa & 8 & 15 \\
\hline Azja & 4 & 7 \\
\hline Ameryka Północna & 2 & $3^{*}$ \\
\hline Ameryka Południowa & 1 & 7 \\
\hline Afryka & 0 & 5 \\
\hline Oceania i Australia & 0 & 4 \\
\hline Razem & 15 & 41 \\
\hline
\end{tabular}

* brak danych dotyczących Stanów Zjednoczonych

Źródło: Na podstawie www.gm.com

General Motors charakteryzuje się wysokim poziomem rozwoju gospodarczego i ogól-noświatową wiedzą. Firma posiada wielką elastyczność w dopasowywaniu indywidualnych produktów do potrzeb indywidualnych klientów na całym świecie. W 1998 r. Generals Motors stworzyło jeden globalny system obsługi, nazwany General Motors Automative. System ten zajmuje się globalnymi procesami, takimi jak projektowanie, wytwarzanie i sprzedaż, a także badaniami rynkowymi, łącznie z komunikowaniem się pomiędzy wszystkimi regionami świata.

Wyróżniono cztery regiony: region Ameryki Północnej (GMNA), Ameryki Łacińskiej, Afryki i Środkowego Wschodu (GMLAAM), region Europy (GME) oraz Azji i Pacyfiku (GMAP). W GMNA produkuje się m.in. Chevroleta, Pontiaca, Oldsmobile i inne (ryc. 3). Grupa GMNA produkuje na rynek Stanów Zjednoczonych (28,8\%), Kanady (30,9\%), Meksyku (25,5\%), Ameryki Środkowej i Wysp Kanaryjskich. W Ameryce Północnej liczba sprzedanych samochodów osobowych w 2001 r. wyniosła 2441 tys. sztuk i w porównaniu z rokiem 1998 spadła o $11 \%$.

Kolejną grupa jest GMLAAM, obejmująca obszar Ameryki Łacińskiej (20\%), Afryki $(13,8 \%)$ oraz Środkowego Wschodu $(8,6 \%)$. Głównie produkuje się na tym terenie Chevroleta, Opla, GMC, Cadillaca. W regionie tym w 2001 r. sprzedano 666 tys. sztuk, o 2\% więcej w porównaniu z rokiem 1998. 
GENERAL MOTORS

\begin{tabular}{|c|c|}
\hline GMNA \\
\cline { 3 - 3 } (GM Ameryki \\
Północnej)
\end{tabular}$\longrightarrow \begin{aligned} & \text { Chevrolet, Pontiac, Oldsmo- } \\
& \text { bile, Buic, Cadillac, GMC, } \\
& \text { Saturn, Hummer, Saab, On } \\
& \end{aligned}$
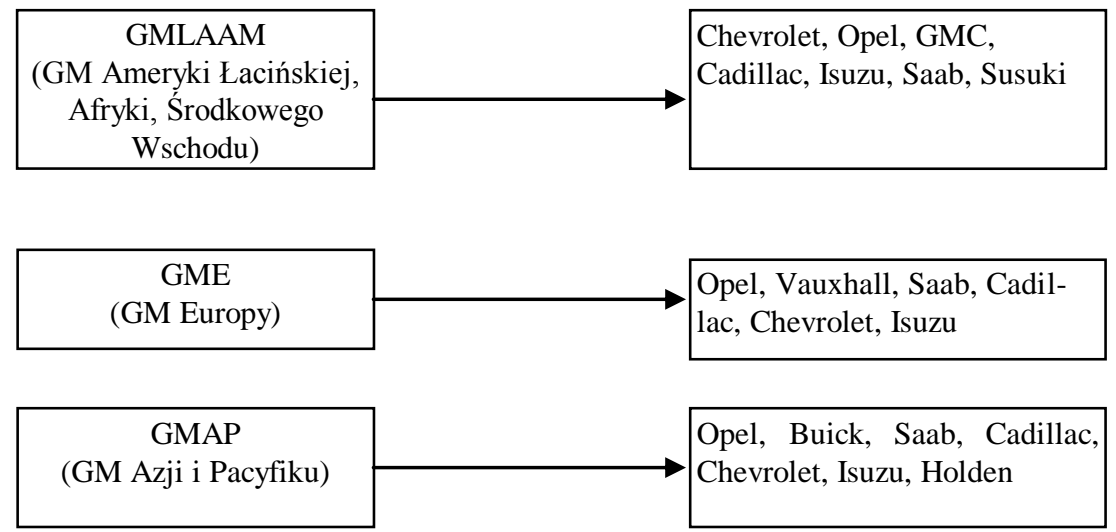

Ryc. 3. Struktura General Motors w 2001 r.

Źródło: Opracowanie własne na podstawie danych jednostkowych (Zalewska 2002)

Następną grupę stanowi obszar europejski GME obejmujący Europę Zachodnią, gdzie udział stanowi 10,4\%, oraz Europę Wschodnią (0,5\%). W Europie w 2001 r. sprzedano 1760 tys. samochodów i w stosunku do 1998 r. sprzedaż spadła o 6\%.

Kolejnym wydzielonym regionem jest GMAP, obejmujący Japonię, Koreę, Chiny, Indie, Australię i Nową Zelandię.

Firma General Motors jest jedną z największych korporacji samochodowych. Jej udział $\mathrm{w}$ światowym przemyśle stanowi 15,1\%, natomiast w Stanach Zjednoczonych 26,9\%, a na obszarze Ameryki Łacińskiej 17,2\%. Obniżenie wartości produkcji spowodowane jest zmniejszającym się popytem na samochody. Wzrosła natomiast sprzedaż na terenie Ameryki Łacińskiej, Afryki i Środkowego Wschodu. Jednak największy udział w globalnej sprzedaży posiada region Ameryki Północnej (64,3\%) oraz Europy $(21,8 \%)$, co łącznie stanowi $\quad 86,1 \%$ i dlatego właśnie te rynki mają wpływ na ogólną tendencję w korporacji.

Zatrudnienie w korporacji kształtuje się obecnie na poziomie 394 tys. osób (2001 r.) i w stosunku do roku 2000 wzrosło o 2\%. Jednak w porównaniu z rokiem 1998 ogólne zatrudnienie w korporacji uległo zmniejszeniu o 3\% (tab. 2). Najwięcej pracowników firma zatrudniała na obszarze GMNA, bo aż 212 tys. Spadek liczby pracowników spowodowany jest zastępowaniem sił i zasobów ludzkich przez automatyzację produkcji. Podobna tendencja wystąpiła na obszarze Europy. Sytuacja na terenie Ameryki Łacińskiej, Afryki i Środkowego Wschodu oraz Azji i Pacyfiku przez 4 kolejne lata nie uległa większym zmianom. 
Tabela 2. Zatrudnienie w General Motors z wyszczególnieniem na regiony w latach 1998-2001

\begin{tabular}{|l|r|r|r|r|}
\hline Zatrudnienie & $1998 *$ & 1999 & 2000 & $2001 * * *$ \\
\hline GMNA & 226 & 217 & 212 & 212 \\
\hline GME & 94 & $91 * *$ & 89 & 88 \\
\hline GMLAAM & 24 & 23 & 24 & 24 \\
\hline GMAP & 10 & 10 & 11 & 11 \\
\hline Hughes & 15 & 18 & 9 & 8 \\
\hline GMAC & 24 & 27 & 29 & 29 \\
\hline inni & 13 & 12 & 12 & 22 \\
\hline Suma GM & 406 & 398 & 386 & 394 \\
\hline
\end{tabular}

Źródło: Na podstawie www.gm.com

Głównym celem firmy jest dążenie do wzrostu dochodów firmy. Korporacja przyjmuje więc strategię opanowania jak największej ilości rynków zagranicznych. Firma działa już

w kilkudziesięciu krajach świata, ale swój rozwój upatruje w strategicznych aliansach z firmami z Azji. Dlatego też właśnie na tym obszarze powstają nowoczesne fabryki i montownie. Do ostatnich inwestycji należy montownia w Szanghaju oraz bardzo nowoczesna montownia

w Tajlandii. Ponadto General Motors współpracuje z innymi firmami. Oprócz rynków azjatyckich korporacja rozwija swoją działalność także w Europie oraz w Ameryce Południowej. Bardzo ważnym elementem strategii firmy jest inowacyjność. Korporacja posiada przewagę nad innymi firmami, głównym jej założeniem jest produkcja bezpiecznych i nowoczesnych samochodów na rynki całego świata, by dzięki skali produkcji obniżyć koszty jednostkowe.

Tabela 3. Procentowy udział sprzedaży samochodów w poszczególnych regionach w $2001 \mathrm{r}$.

\begin{tabular}{|l|c|r|r|r|}
\hline & 1998 & 1999 & 2000 & 2001 \\
\hline \multicolumn{5}{|c|}{ GMNA } \\
\hline Samochody & 34,0 & 34,1 & 33,5 & 30,2 \\
\hline Ciężarówki & 29,2 & 32,8 & 32,5 & 34,0 \\
\hline Suma & 63,2 & 66,9 & 66,0 & 64,3 \\
\hline \multicolumn{5}{|c|}{ GME } \\
\hline Samochody & 22,0 & 20,8 & 19,9 & 20,6 \\
\hline Ciężarówki & 1,5 & 1,6 & 1,5 & 1,2 \\
\hline Suma & 23,5 & 22,4 & 21,5 & 21,8 \\
\hline \multicolumn{5}{|c|}{ GMLAAM } \\
\hline Samochody & 5,0 & 4,0 & 5,0 & 5,7 \\
\hline Ciężarówki & 3,1 & 2,0 & 2,3 & 2,5 \\
\hline Suma & 8,1 & 6,0 & 7,2 & 8,2 \\
\hline
\end{tabular}




\begin{tabular}{|l|c|c|c|c|}
\hline \multicolumn{5}{|c|}{ GMAP } \\
\hline Samochody & 2,5 & 1,8 & 2,0 & 2,5 \\
\hline Ciężarówki & 2,7 & 2,9 & 3,2 & 3,2 \\
\hline Suma & 5,2 & 4,8 & 5,2 & 5,7 \\
\hline Ogółem & 100,0 & 100,0 & 100,0 & 100,0 \\
\hline
\end{tabular}

Źródło: Na podstawie www.gm.com

Korporacja General Motors jest liderem na rynku światowym. Jej udział w 2000 r. w produkcji samochodów stanowił 15\%. Dla porównania udział Forda stanowił 12,3\%, Toyoty 10\%, Daimlera Chryslera 8,8\%, a Volkswagena 8,7\%. Te pięć wymienionych firm łącznie obejmowało $54,8 \%$ światowego rynku samochodowego.

Sprzedaż samochodów General Motors od roku 1998 jest bardzo wyrównana i kształtuje się na poziomie $8 \mathrm{mln}$ sztuk rocznie.

Tabela 4. Udział General Motors w światowym przemyśle

\begin{tabular}{|l|c|c|c|c|c|}
\hline & 1997 & 1998 & 1999 & 2000 & 2001 \\
\hline Stany Zjednoczone & 32,5 & 30,17 & 29,8 & 26,6 & 26,9 \\
\hline Samochody & 28,7 & 27,45 & 27,8 & 27,0 & 29,2 \\
\hline Ciężarówki & 30,7 & 28,84 & 28,8 & 27,8 & 28,1 \\
\hline Razem Stany Zjednoczone & 28,6 & 26,56 & 26,7 & 26,7 & 24,7 \\
\hline Razem Kanada i Meksyk & 30,5 & 28,54 & 28,5 & 27,7 & 27,6 \\
\hline GMNA & 10,1 & 9,62 & 9,7 & 9,3 & 9,2 \\
\hline GMLAAM & 17,0 & 15,65 & 16,0 & 16,3 & 17,2 \\
\hline GMAP & 4,4 & 4,00 & 3,9 & 3,7 & 3,9 \\
\hline Suma Świat & 16,0 & 15,52 & 15,6 & 15,1 & 15,1 \\
\hline
\end{tabular}

Źródło: Na podstawie www.gm.com

Firma General Motors, założona w 1908 r. w Stanach Zjednoczonych Ameryki Północnej, jest obecnie największą światową firmą produkującą samochody. Należy do czołówki korporacji samochodowych. W 2001 r. wśród wszystkich globalnych firm zajmowała 3. pozycję, a jej przychody wśród 15 największych koncernów samochodowych stanowiły 16,7\%. Kolejne miejsce zajmowały firmy: Ford (15,3\%), Daimler Chrysler $(12,9 \%)$, Toyota $(11,4 \%)$. Dochód czterech wyżej wymienionych korporacji stanowi 56,3\% wszystkich wyszczególnionych 15 koncernów samochodowych.

Tabela 5. Potentaci samochodowi na świecie w 2001 r.

\begin{tabular}{|r|l|c|c|c|}
\hline Lp. & \multicolumn{1}{|c|}{ Firma } & $\begin{array}{c}\text { Pozycja w ran- } \\
\text { kingu Global 500 }\end{array}$ & Dochód & $\begin{array}{c}\text { Udział } \\
\text { procentowy dochodu }\end{array}$ \\
\hline 1 & GM & 3 & 177260 & 16,7 \\
\hline 2 & Ford & 5 & 162412 & 15,3 \\
\hline 3 & Daimler Chrysler & 7 & 136897 & 12,9 \\
\hline 4 & Toyota & 10 & 120814 & 11,4 \\
\hline 5 & Volkswagen & 21 & 79287 & 7,5 \\
\hline 6 & Honda & 41 & 58882 & 5,5 \\
\hline 7 & Fiat & 49 & 51944 & 4,9 \\
\hline 8 & Nissan & 58 & 49555 & 4,7 \\
\hline 9 & Peugeot & 65 & 46264 & 4,4 \\
\hline 10 & BMW & 112 & 34443 & 3,2 \\
\hline
\end{tabular}




\begin{tabular}{|l|l|r|r|r|}
\hline 11 & Renualt & 125 & 32552 & 3,1 \\
\hline 12 & Hundai & 133 & 30863 & 2,9 \\
\hline 13 & Robert Bosch & 135 & 30472 & 2,9 \\
\hline 14 & Delphi & 166 & 26088 & 2,5 \\
\hline 15 & Mitshubishi & 171 & 25598 & 2,4 \\
\hline 16 & Razem & & 1063331 & 100,0 \\
\hline
\end{tabular}

Źródło: Obliczenia własne na podstawie danych ze strony www.fortune.com

Tabela 6. Potentaci samochodowi w Stanach Zjednoczonych w 2001 r.

\begin{tabular}{|c|c|c|c|c|c|c|}
\hline \multirow[b]{2}{*}{ Lp. } & \multirow[b]{2}{*}{ Firma } & \multirow{2}{*}{$\begin{array}{c}\text { Pozycja } \\
\text { w rankingu } \\
\text { Fortune } 500\end{array}$} & \multirow{2}{*}{$\begin{array}{c}\text { Dochód } \\
\text { w mln USD }\end{array}$} & \multirow[b]{2}{*}{ Zatrudnienie } & \multicolumn{2}{|c|}{ Struktura } \\
\hline & & & & & dochodu & zatrudnienia \\
\hline 1 & General Motors & 3 & 177260 & 365000 & 37,2 & 24,0 \\
\hline 2 & Ford & 4 & 162412 & 352748 & 34,1 & 23,2 \\
\hline 3 & Delphi & 67 & 26088 & 195000 & 5,5 & 12,8 \\
\hline 4 & Johnson Controls & 111 & 18427 & 112000 & 3,9 & 7,4 \\
\hline 5 & Visteon & 114 & 17843 & 56300 & 3,7 & 3,7 \\
\hline 6 & TRW & 122 & 16383 & 93700 & 3,4 & 6,2 \\
\hline 7 & Goodyear & 144 & 14147 & 96430 & 3,0 & 6,3 \\
\hline 8 & Lear & 150 & 13625 & 115929 & 2,9 & 7,6 \\
\hline 9 & Dana & 183 & 10469 & 70000 & 2,2 & 4,6 \\
\hline 10 & ArvinMeritor & 275 & 6805 & 33000 & 1,4 & 2,2 \\
\hline 11 & NavistarInternat & 280 & 6722 & 16500 & 1,4 & 1,1 \\
\hline 12 & Paccar & 295 & 6089 & 16000 & 1,3 & 1,1 \\
\hline 13 & Razem & & 476270 & 1522607 & 100,0 & 100,0 \\
\hline
\end{tabular}

Źródło: Obliczenia własne na podstawie danych ze strony www.fortune.com

Warto zwrócić uwagę, iż dochód General Motors i Ford w Stanach Zjednoczonych stanowił 71,3\% dochodu wyróżnionych 12 firm.

Firma General Motors główny nacisk kładzie na fuzje i przejęcia. Aktualnie firma formuje jeszcze skuteczniejsze alianse $\mathrm{z}$ już istniejącymi firmami, chcąc $\mathrm{w}$ ten sposób zdobyć rynek Azji i Pacyfiku. W ostatnich latach dużemu zachwianiu uległ rynek azjatycki. Nagłe zubożenie społeczeństw Japoni, Indonezji, Malezji i Tajlandii spowodowało spadek popytu na samochody. Niektóre z firm japońskich, np. Suzuki, zawarły porozumienie z General Motors, dzięki czemu uzyskały nowy odległy rynek zbytu, natomiast GM partnera produkującego zwinne samochody, których brakowało firmie.

Firma General Motors jest potęgą gospodarczą. Kondycja tego największego pod względem obrotów przedsiębiorstwa motoryzacyjnego na świecie poprawiła się znacznie w latach 90. Zmusiło to zarząd firmy do dokonania zmian. Początkowo koncepcja rozwoju firmy zakładała, że GM sama wytwarza prawie wszystko, co jej potrzebne. Ten model okazał się jednak nieskuteczny w ramach globalizacji rynków i zaostrzania konkurencji. Obecnie zmieniła się strategia firmy. Wprowadza ona innowacje, dba o bezpieczeństwo użytkowników samochodów, a nowe rynki zdobywa poprzez fuzje i przejęcia. Aby osiągnąć wzrost dochodów, firma przyjmuje strategię opanowania jak największej ilości rynków zagranicznych. Swój rozwój upatruje w strategicznych aliansach z firmami azjatyc- 
kimi. Dlatego też na terenie Azji powstają nowoczesne fabryki i montownie. Poza tym rozszerza także swoją działalność na teren Europy i Ameryki Południowej. Produkty GM są nowoczesne, a wprowadzane innowacje pozwalają utrzymywać wciąż wysoką pozycję na rynku globalnym.

Firma General Motors należy do koncernów ponadnarodowych. Ambicją jej jest zdobywanie coraz to nowych rynków, zwłaszcza rynków azjatyckich, a celem osiągnięcie pozycji ogólnoświatowego producenta. Aby to osiągnąć, firma dąży do inwestowania w badania naukowe, dzięki którym możliwa jest produkcja coraz nowocześniejszych samochodów.

\section{Literatura}

Budnikowski A., 2001, Międzynarodowe stosunki gospodarcze, Warszawa

Liberska B., 2002, Globalizacja, mechanizmy $i$ wyzwania, Warszawa

Zalewska K., 2002, „Kształtowanie się ponadnarodowej firmy General Motors”, praca magisterska wykonana w Zakładzie Przedsiębiorczości i Gospodarki Przestrzennej Instytutu Geografii Akademii Pedagogicznej w Krakowie, pod kierunkiem prof. Z. Zioło

Zioło Z., 2001, Współczesne tendencje rozwoju przemystu i ich problematyka badawcza, [w:] Problematyka przemian struktur przestrzennych przemystu, red. Z. Zioło, Prace Komisji Geografii Przemysłu PTG nr 2, Kraków

Zioło Z., 2001, Struktura branżowa i koncentracja przestrzenna wiodacych światowych firm przemysłowych, [w:] Problemy przemian struktur przemystowych $w$ procesie wdrażania regut gospodarki rynkowej, red. Z. Zioło, Prace Komisji Geografii Przemysłu PTG nr 3, KrakówRzeszów

www.fortune.com

www.gm.com 